INTERDISCIPLINARIA ARCHAEOLOGICA NATURAL SCIENCES IN ARCHAEOLOGY

\title{
New Plants at Prague Castle and Hradčany in the Early Modern Period: a History of Selected Species
}

\author{
Jaromír Beneša, Věra Čulíkovác, Jitka Kosňovskáa, Jan Frolík ${ }^{\mathrm{b}}$, Josef Matiášek ${ }^{\mathrm{b}}$ \\ ${ }^{a}$ University of South Bohemia, Laboratory of Archaeobotany and Palaeoecology, Faculty of Science, Branišovská 31,37005 České Budějovice, Czech Republic \\ ${ }^{b}$ Institute of Archaeology, Academy of Sciences, Letenská 4, 11801 Prague 1, Czech Republic \\ 'Institute of Archaeology, Academy of Sciences, workplace Bezručovo náměstí 1, 74601 Opava, Czech Republic
}

\section{ARTICLE INFO}

\section{Article history:}

Received: 15 May 2012

Accepted: 19 June 2012

Key words:

Prague Castle

archaeobotany

Early Modern Period

imported plants

globalisation

\begin{abstract}
$A B S T R A C T$
In the Early Modern period, Prague Castle was not only the core of the Bohemian Kingdom, but also one from centres of the economic and political life for all of central Europe. In recent decades, archaeological excavations discovered valuable features and deposits with archaeobotanical assemblages containing unusual and exotic plants, some of them a first in the region and in Europe. The article describes new plants as part of the material world of human society reflecting the high social status of the castle and the town inhabitants. The new species originate from various regions of the world and reflect the first wave of globalisation of the urban environment in central Europe. The ethnobotanical histories of the particular new plants are described.
\end{abstract}

\section{Introduction}

Prague Castle was the historical core of the Bohemian Kingdom (Figure 1). This residency of early medieval Bohemian dukes and medieval kings was also a crossroads of economic activity in the Early Modern period. The complex of Prague Castle and the nearby Hradčany town has been therefore one of the most important fields of archaeological activity since 1925 (Borkovský 1969; Frolík, Smetánka 1997). Prague Castle as the central point of Bohemia is an extremely valuable site in terms of environmental archaeology. Finds of imported species (Čulíková 1995; 2007; 2008) and raw materials (Beneš et al. 2006) are a key element testifying to the significance of the central area of Prague in the context of the development of all of central Europe. Research into layers, finds and situations from the Early Modern period have in recent years become an attractive topic for bioarchaeological studies at Prague Castle and its surroundings (Čulíková 1995; 1998; 2001; 2007; 2008; 2012). The following article summarises important

"Corresponding author. E-mail: benes.jaromir@gmail.com new archaeobotanical discoveries made in the context of the Early Modern period at Prague Castle and Hradčany. Primary attention is paid to particular plant species, their origin, significance, cultural meaning, and the role of the Emperor and royal courts in the Early Modern period.

During the $16^{\text {th }}$ century, the ambitious Habsburg family ruled over a large part of Europe, including Spain and part of the Burgundy heritage, the Netherlands. Thanks to their numerous contacts abroad, the Bohemian nobility began to become more cosmopolitan in nature. Prague Castle experienced its greatest revival during the reign of Rudolf II (1576-1611), who relocated his court from Vienna to Prague in 1583. The new incoming court aristocracy came primarily from the German lands, but also enjoyed close ties with the Netherlands and with the Spanish Kingdom. Rudolf II was actually brought up in this court and the lifestyle of the Spanish aristocracy inspired him significantly. His ties to the Spanish court allowed them to become acquainted not only with the lifestyle of Southern and Western Europe, but also with information on overseas discoveries in America, the exploitation of which became the driving force of the Spanish economy. Prague Castle became the cultural centre of central Europe at the 


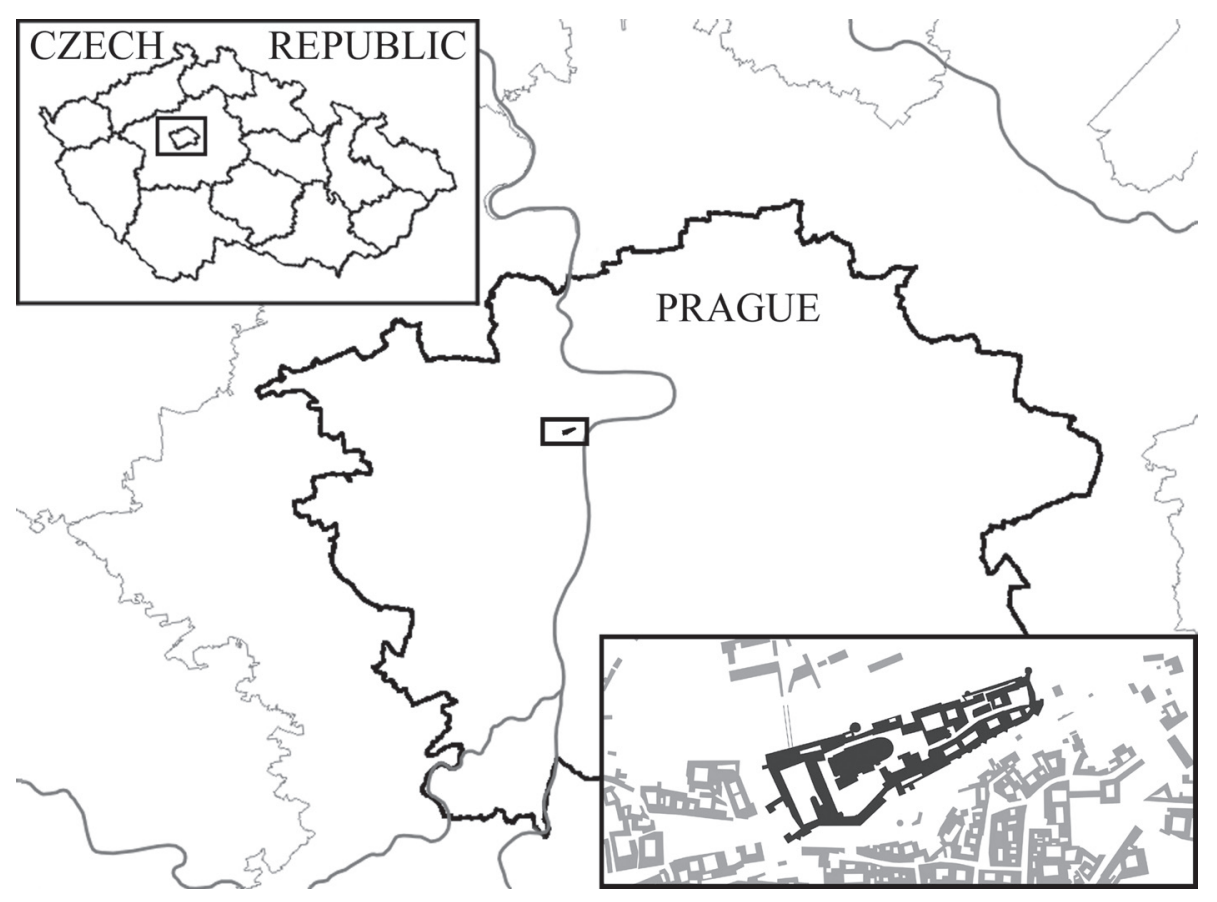

Figure 1. Prague Castle and Hradčany and their location in the Czech Republic. Drawing by J. Matiášek.

turn of the $17^{\text {th }}$ century. Lively relations were maintained not only with the west, but also with the rest of Europe (primarily the Italian states), and with Asia. For this reason, imports of luxury goods and plants from America and the Mediterranean found their way to Bohemia, as did Turkish coins (Frolík, Novák 2007) and Chinese porcelain. All the archaeobotanical finds reflect Prague Castle and its western foregrounds (the town of Hradčany) in the $16^{\text {th }}$ and $17^{\text {th }}$ centuries as a milieu in which news was received quickly from the New World and the Near and Far East. The knowledge and use of new luxury plants spread from Prague Castle to Hradčany via the nobility connected to the Emperor's court and by officers of the Czech royal orders. New archaeobotanical evidence has been discovered at the following localities.

\section{Material and methods}

Our research is based on archaeobotanical evidence of particular species from several archaeological sites and locations, which were investigated over the last two decades in the area of Prague Castle and Hradčany and have only been published in Czech archaeological and historical journals. Archaeobotanical investigation at the site of Vladislav Hall is still in progress. Botanical material obtained from the archaeological sites was prepared for macro-remains analyses by traditional methods using flotation or wet sieving based on the sieve system. Macro-remains from the waste vault infill of Vladislav Hall were separated by a combination of methods of dry sieving, flotation and a hand-picked collection. For the macro-remains determination, a laboratory reference collection and atlases (Cappers et al. 2006; 2009; Anderberg 1994; Berggren 1981) were used. The botanical names reflect the Czech botanical nomenclature by Kubát
(2002). Imported and introduced new plants from different locations in Prague Castle and the immediate surroundings were selected from particular field datasets and evaluated in their archaeobotanical and historical context.

\section{Results. The archaeological context of the new and imported plant remains}

As part of the salvage archaeological excavations in Hradčany, Kanovnická street 73 (Figure 2A) two cesspits (B and E) from the Early Modern period were exposed (excavation director: J. Frolík in 1983-1985). Both cesspits formed part of a larger depositional waste system, dated to the end of the $16^{\text {th }}$ century and the first half of the $17^{\text {th }}$ century. The cesspits contained faecal deposits supported by evidence of a latrine wooden board found at this site (Frolík 1987). The layer contained specific artefacts and botanical finds which suggested its origin within a short period. Approximately, 30,000 botanical macro-remains were classified under 175185 taxons, while $60 \%$ may be considered as useful plants (Čulíková 1995; 2008). Approximately 100 species exhibited pharmaceutical-type properties. The extraordinary value of the spices and medicinal plants in all probability reflects hospital and pharmaceutical activities. Value kinds of useful plants were recorded here. They represent plants imported to the Early Modern milieu of Bohemia and plants from southern European regions, Asia and the Americas: melon (Cucumis melo), rice (Oryza sativa), common box (Buxus sempervirens), common fig (Ficus carica), rustic tobacco (Nicotiana rustica), pumpkin (Cucurbita pepo) and spices and medicinal herb such as coriander (Coriandrum sativum), fennel (Foeniculum vulgare), which are rarely represented in archaeobotanical assemblages. 


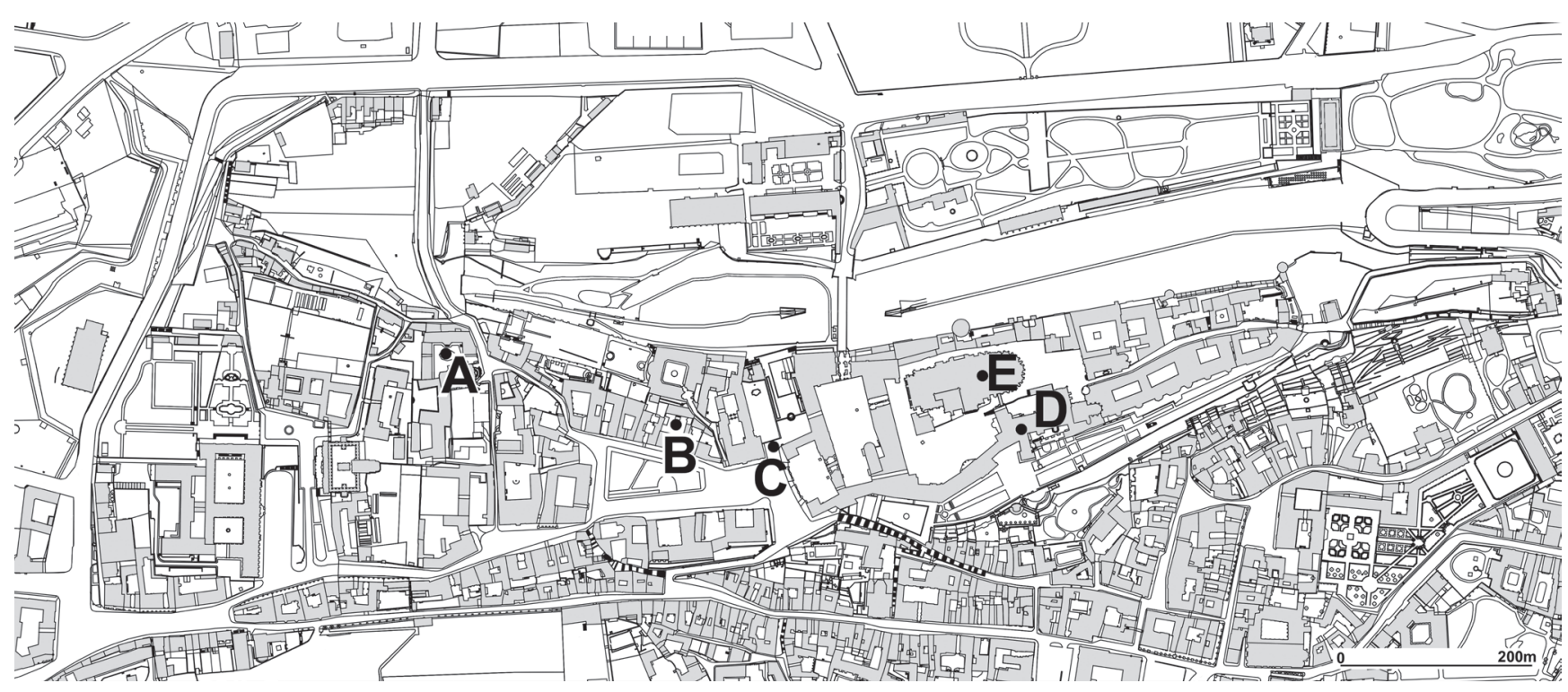

Figure 2. Location of particular archaeobotanical assemblages in the area of Prague Castle and Hradčany: A - Kanovnická street 73, B - Hradčany square 60, C - Hradčany square: sewage tunnel, D - Prague Castle, Vladislav Hall, E - Prague Castle, royal tomb. Drawing by J. Matiášek.

Archaeological and archaeobotanical finds in a cesspit in Hradčany, Hradčany Square 60 (Figure 2B) were identified in the NW court corner of the house (excavation director: K. Tomková). The dark organic layer numbered No. 9 with fragments of sherds, animal bones, Renaissance glass and other finds at a depth of 625-695 cm, can be interpreted as a sedimentary deposit. The archaeological assemblage of layer 9 can be dated to the $17^{\text {th }}$ century. Only volume 1,81 has been provided for archaeobotanical analysis. However, more than 3500 seeds, fragments of charcoal and other remains have been obtained. The collection included the most frequently collected species, notable useful plant species were recorded only by an individual seed. No other kinds of crops, primarily spices and healing plants of a foreign origin, were obtained over the entire spectrum of species consisting of just over 70 taxa of herbs and woody plants (some of ambiguous determination). According to the archaeobotanical results from a nearby sewage tunnel (see below), legumes were not found and finds of cereals and imported rice (Oryza sativa) were only seldom recorded. Valuable fruits were represented by sugar melon (Cucumis melo). The occurrence of currant (Ribes rubrum), the cultivated form, in the form of dozens of seeds, was identified in the cesspit assemblage.

A number of portrayals of Prague Castle from the Renaissance period depict a huge moat between the western edge of Prague Castle and Hradčany Square (Figure 2C). Archaeological salvage excavations in 1993 used an 8 m deep shaft between the Archbishop's palace and Prague Castle's IV court gate (excavation director I. Herichová). Archaeological layers in the shaft that were situated in part of the moat contained a mixture of waste and building material and can be dated to the $16^{\text {th }}$ century $/ 18^{\text {th }}$ century. A wooden sewage tunnel was discovered in the central part of the moat. The sewage tunnel is dated to 1581 , and was constructed at the order of Emperor Rudolf II. The base of the tunnel contained a sequence of sandy and mud layers formed by transport and sedimentation in a wet environment. Archaeobotanical finds originated in layers 117 and 125. On Hradčany Square, a series of samples from two locations were analysed by V. Čulíková in 2005. Two samples (volumes 2, 2 and 4, 5 1) came from sediments at the base of the wooden sewage tunnel in front of the Archbishop's palace. Moist organic layers have been archaeologically dated to the turn of the $17^{\text {th }}$ century. Altogether, 5,500 botanical macro-remains were analysed containing 150-160 species. After useful species, most frequent were ruderal plants; among others jimson weed (Datura stramonium) was recorded. This species is a neophyte from America, recorded for the first time in 1809 in historical sources (Pyšek et al. 2002). Its 33 seeds could be the remains of a certain pharmaceutical product. Spices and medicinal plants prevailed in assemblage, followed by fruit and oil plants both used as medicine. With the exception of millet (Panicum miliaceum) cereals and pulses were missing. From oil plant hemp (Cannabis sativa) and poppy (Papaver somniferum) were present. Determination of one seed of goosberry (Grossularia uva-crispa) remains unclear, while different types of currant seeds (Ribes nigrum, $R$. cf. rubrum, $R$. cf. petraeum/sylvestre) were frequently presented. Spices and medicinal herbs of Mediterranean or Asiatic origin were probably locally produced. Recorded were dill (Anethum graveolens), celery (Apium graveolens), parsley (Petroselinum hortense), coriander (Coriandrum sativum), fennel (Foeniculum vulgare), garden pepperwort (Lepidium sativum), marjoram (Majorana hortensis), basil (Ocimum basilicum), and summer savory (Satureja hortensis). These were the first records of Lepidium and Ocimum in the Czech Republic, and of Majorana in Bohemia. Exotic spices were represented by black pepper (Piper nigrum), specifically white pepper, which is a special product of $P$. nigrum, obtained by different handling after harvesting in comparison with the 


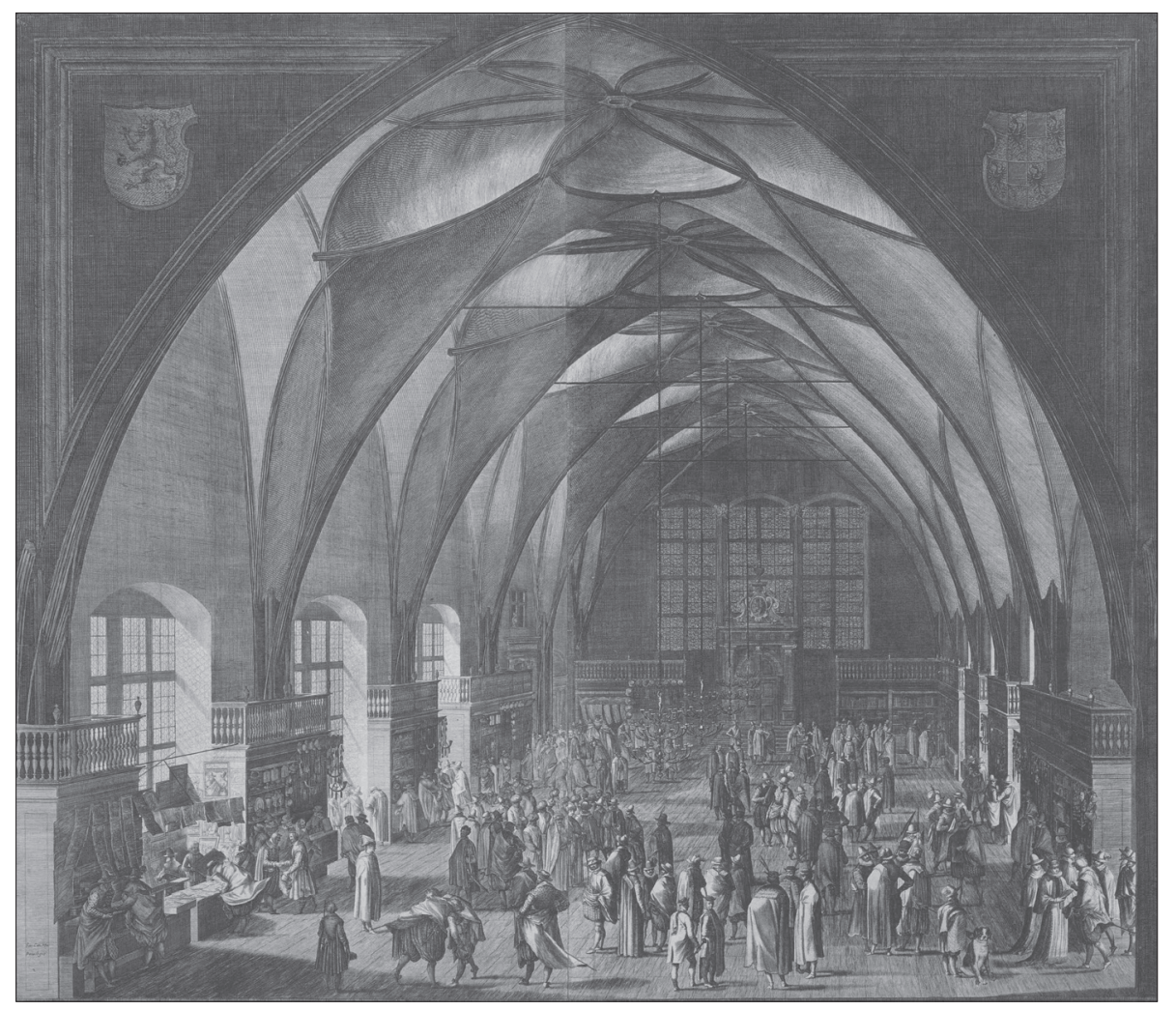

Figure 3. Vladislav Hall. Aegidius Sadeler copper engraving from the year 1607 depicting the trade and social life in the hall.

black pepper product (de Waard, Anunciado 1999). Useful plants of American origin included rustic tobacco (Nicotiana rustica) and american pokeweed (Phytolacca americana).

The Prague Castle Vladislav Hall (Figure 2D) was built at the impetus of King Ladislaus Jagiello between 1490 1502 (Kalina 2009; Hořejší 1973). The hall with five helical arch fields was incorporated into the older medieval palace (Figure 3). The building was damaged after a devastating fire in Malá Strana and Hradčany in 1541. The hall was used for ceremonial events for the royalty and nobility, with equestrian knight tournaments being another type of event practised here. Royal ceremonies prevailed, particularly during the coronation banquets of the Habsburgs. The hall also served as a marketplace providing luxury goods, art and book print production. It also functioned as a place for social gathering. At present, the hall is used for important political ceremonies, such as the election and inauguration of the President of the Czech Republic. In 2008-2009, during the restoration of the wooden floor, an archaeological excavation was undertaken (excavation directors J. Frolík and J. Matiášek). The fill of the vault under the floor of Vladislav Hall was of varying quality, reflecting a state of preservation and modern disturbance. The remains of a floor, no longer used due to a fire in 1541, were identified in the eastern part of the hall. The layers consisting of building waste were filled by homogeneous layers of dusty deposits with an extremely high content of the material culture from the $16^{\text {th }}$ century and the beginning of the $17^{\text {th }}$ century. The dry conditions of the waste fill in Vladislav Hall allowed for perfect preservation of the macro-remains. The archaeobotanical complex, analysed by J. Kosňovská, consisted mainly of woodwork-related waste, kitchen and dining waste and building supplies. This mixture of waste was primarily made up to specifically provide isolation beneath the wooden floor. The archaeobotanical analysis of the waste fill is based on two types of samples. The first group of samples, obtained by dry sieving, captured large macro-remains predominantly with species of fruit (plums, hazelnuts and walnuts, grapes, etc.). These results were supplemented by numerous findings of groups of small seeds obtained by flotation. Based on this analysis, the social life of the Early Modern period of Prague Castle and the agricultural activities from its immediate vicinity, or more distant surrounding areas, can be reconstructed. Among the less common species recorded in the archaeobotanical complex of Vladislav Hall assemblage were olive (Olea europaea), sweet almond (Prunus dulcis), sweet chestnut (Castanea sativa), peanut (Arachis hypogaea), pistachio nut (Pistacia vera) and coffee (Coffea arabica). All of these plant products are unique in the archaeobotanical context in central Europe (Kosňovská 2011).

From the $10^{\text {th }}$ century onwards, Saint Vitus Cathedral and additional churches in Prague Castle became key burial places for the Bohemian ruling dynasties. The Royal Tomb in Saint Vitus Cathedral (Figure 2E) is the focal point. After the Přemyslid and Luxembourg families, the first Habsburgs on the Czech throne (only Rudolf I of Habsburg in 1307) are also buried there, i.e. Ferdinand I, his wife Anna Jagiello, the son of Maximilian II and his grandson Rudolf II and the archduchess Eleanor. The last daughter of Maximilian II, Eleanor (15681580), died in Prague Castle on $1^{\text {st }}$ March and was buried on $18^{\text {th }}$ March 1580 in the ancient Royal Tomb. Ten years afterwards, her relics and the remains of additional persons 
Figure 4. Saint Vitus Cathedral. Royal tomb. Burial of Princess Eleanor during anthropological research. Photo courtesy of the Prague Castle archive.

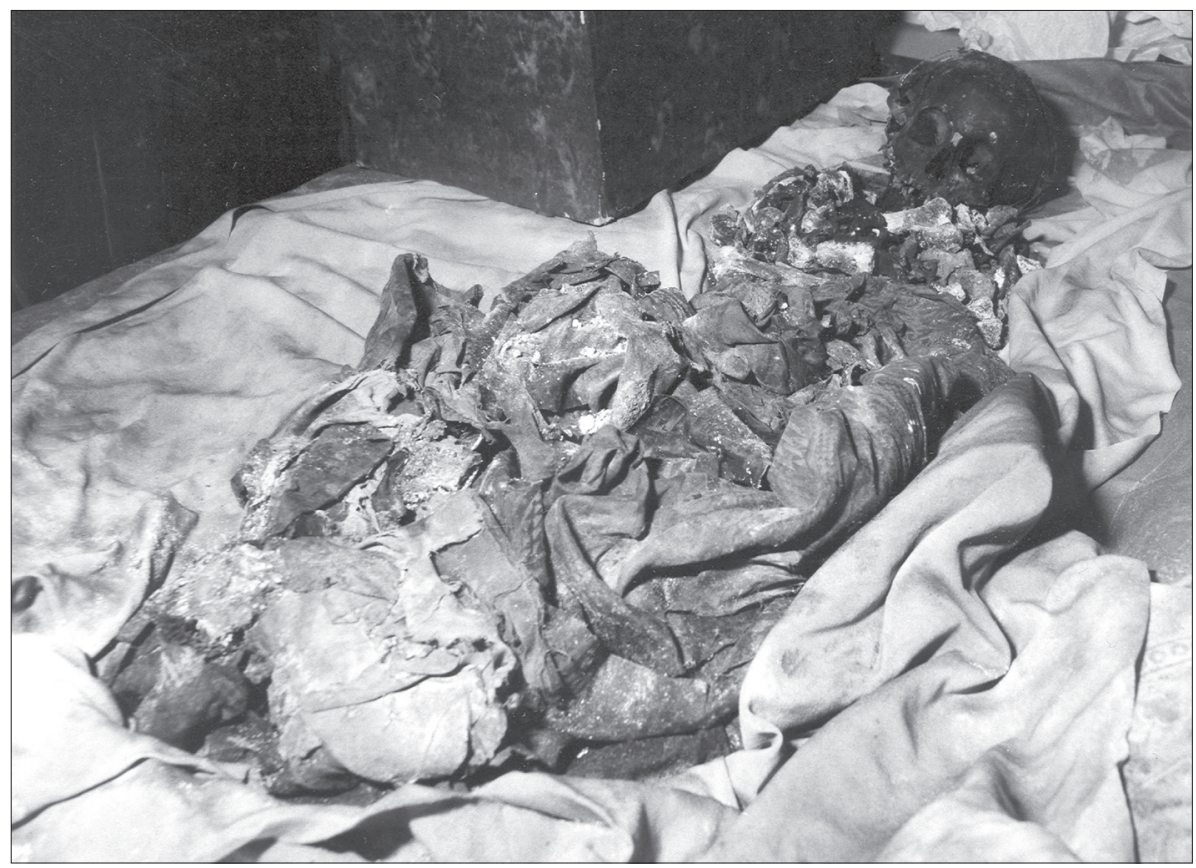

were transferred to the new Royal Tomb with a mausoleum. In 1935, the remains of Eleanor were laid in a joint coffin together with her ascendants, Duke Rudolf of Habsburg and King Rudolf I of Habsburg. This coffin was opened in 1991 for research and preservation reasons (Figure 4).

Anthropological investigation suggests that her underdeveloped skeleton is a testament to her frequent illnesses. She was buried in white damask clothing with large Spanish-style flower ornamentation. The head of the unmarried Eleanor was decorated with a coronet, and a wreath of bitter orange leaves (Citrus aurantium) and rosemary leaves (Rosmarinus officinalis) was placed on her breast (Schoch 1996). Clasped in her hands were plant remains of a laurel-like gift devoted to the twelve year old princess.

\section{Discussion. Imported and introduced plants and their history}

Among the hundreds of botanical species identified in the context of the above-mentioned, five archaeological sites at Prague Castle are unique with findings of new plants (Table 1). The shared characteristics of all of these species are their origin in distant countries, primarily in the Mediterranean regions. Certain commodities are from Asia and Africa. The botanical provenance of american pokeweed, peanut, pumpkin and rustic tobacco is the New World. The concentration of the latter species at Prague Castle, in the Early Modern period context, is quite unique. Selected plant species are discussed below in the context of their origin and ethnobotanical history.

American pokeweed (Phytolacca americana L.) (Figure 5): One seed of the North American species pokeweed (Phytolaccaceae), found in the sewage tunnel, represents a unique finding among all European archaeobotanical collections from the Early Modern period. Additionally, seed of tobacco, spices and pharmaceuticals were also recorded at the same site Hradčany Square. Not only were the dark purple berries of $P$. americana used for food dyeing, but the roots were also used for medicinal purposes and the leaves were cooked as a spinach-type vegetable in America. The cultivation of this species (P. americana) for berries in Europe was started by wine makers on the Pyrenean peninsula. The cultivation and employment of american pokeweed reached France, Italy and Germany, where it became a new introducted plant, which occasionally escape from cultivation. (Čulíková 2007, 355). The juice of the ripe berries was used to colour wine and liqueur, but as they are slightly toxic in most countries it is obsolete or even forbidden (Büttner 2001, 191). From the $19^{\text {th }}$ century up until the Second World War, the escaped and naturalized plants of $P$. americana was also known in the Czech lands. In the fifties of $20^{\text {th }}$ century was this species in nature of the Czech Republic replaced by the eastern Asian Phytolacca esculenta. We do not know in which state (fresh or dried), were the berries of $P$. americana (plant kermes berry) transported from Southern Europe to Renaissance Prague. The utilisation of pokeweed for food dyeing (mostly for sweets) or as a medicinal plant for gout, rheumatism and stomach treatment is a viable possibility. Another possibility is the planting of the mighty $P$. americana herb in the royal gardens, for example, near the royal garden behind the Stag Moat (Ferdinand I bought the vineyards in 1534 for the purposes of setting up a royal garden).

$P$. americana was used in Czech countries up untill $20^{\text {th }}$ century. The new archaeobotanical findings in Prague indicate that both rustica tabacco and pokeweed could have been already cultivated in the gardens, especially in the Royal Botanical garden in Renaissance as pharmaceutical or unusual ornamental plants. 
Table 1. List of imported and introduced plants and their presence in archaeological assemblages A-E. Abbreviations: ca - caryopsis; fru - fruit; le - leaf; lem - lemma; pod - pod; s - seed; fr. - fragment.

\begin{tabular}{|c|c|c|c|c|c|c|c|}
\hline Scientific name & Engl. name & Macrofossil & $\mathbf{A}$ & $\mathbf{B}$ & $\mathbf{C}$ & D & $\mathbf{E}$ \\
\hline$\overline{\text { Arachis hypogaea } \mathrm{L} .}$ & peanut & pod & & & & $4 \mathrm{fr}$. & \\
\hline Buxus sempervirens L. & commom box & le & $68+41 \mathrm{fr}$. & & & 10 & \\
\hline Castanea sativa Mill. & sweet chestnut & fru & & & & $93 \mathrm{fr}$. & \\
\hline Citrus aurantium $\mathrm{L}$. & bitter orange & le & & & & & 10 \\
\hline Citrus cf. reticulata Blanco & mandarin orange & $\mathrm{s}$ & & & & 1 & \\
\hline Citrus sinensis (L.) Osbeck & sweet orange & $\mathrm{s}$ & & & & 2 & \\
\hline Coffea arabica $\mathrm{L}$. & coffee & $\mathrm{s}$ & & & & 1 & \\
\hline Coriandrum sativum L. & coriander & fru & 9 & & & $5+2$ fr. & \\
\hline Cucumis melo $\mathrm{L}$. & melon & $\mathrm{s}$ & $2+1$ fr. & & & 1 & \\
\hline Cucurbita pepo L. & pumpkin & $\mathrm{s}$ & $4+11$ fr. & & & 6 & \\
\hline Datura stramonium L. & jimson weed & $\mathrm{s}$ & & & 33 & & \\
\hline Ficus carica $\mathrm{L}$. & common fig & fru & $4,300+21$ fr. & $618+5 \mathrm{fr}$. & $263+2$ fr. & 5 & \\
\hline Foeniculum vulgare Mill. & fennel & fru & 2 & & 2 & & \\
\hline Lepidium sativum $\mathrm{L}$. & garden pepperwort & $\mathrm{s}$ & & & 1 & & \\
\hline Majorana hortensis Moench & marjoram & fru & & & $3+1$ fr. & & \\
\hline Mespilus germanica $\mathrm{L}$. & medlar & $\mathrm{s}$ & 12 & & & & \\
\hline Nicotiana rustica L. & rustic tabacco & $\mathrm{s}$ & 1 & & 1 & & \\
\hline Ocimum basilicum $\mathrm{L}$. & basil & fru & & & 2 & & \\
\hline Olea europaea L. & olive & st & & & & $20+2 \mathrm{fr}$ & \\
\hline \multirow{2}{*}{ Oryza sativa L. } & \multirow{2}{*}{ rice } & $\mathrm{ca}$ & 2 & & & & \\
\hline & & lem & $1 \mathrm{fr}$. & & & & \\
\hline Phytolacca americana $\mathrm{L}$. & american pokeweed & $\mathrm{s}$ & & & 1 & & \\
\hline cf. Pimpinella anisum $\mathrm{L}$. & aniseed & fru & & 6 & & & \\
\hline Piper nigrum $\mathrm{L}$. & black pepper & s & & & 1 & & \\
\hline Pistacia vera $\mathrm{L}$. & pistachio & $\mathrm{s}$ & & & & 1 & \\
\hline Prunus dulcis (Mill.) D.A. Webb & sweet almond & st & & & $3 \mathrm{fr}$. & & \\
\hline Ribes cf. nigrum L. & black currant & s & & & 1 & & \\
\hline Ribes rubrum $\mathrm{L}$. & red currant & $\mathrm{s}$ & & $35+9$ fr. & & & \\
\hline Rosmarinus officinalis L. & rosemary & le & & & & & 6 \\
\hline Satureja hortensis L. & summer savory & fru & & & 1 & & \\
\hline
\end{tabular}

Citrus fruit (Citrus L. sp.): Several valuable findings of citruses, plants that belong to the Rutaceae family, have been found in the area of Prague Castle (Table 1). Bitter orange (sour orange, Citrus aurantium) was found in the grave of Princess Eleanor. Sweet orange (Citrus sinensis - Figure 6), and mandarin orange (Citrus cf. reticulata) were found in the Vladislav Hall vault infill dated back to the $16^{\text {th }}$ century and to the first half of the $17^{\text {th }}$ century. Citrus fruits were cultivated

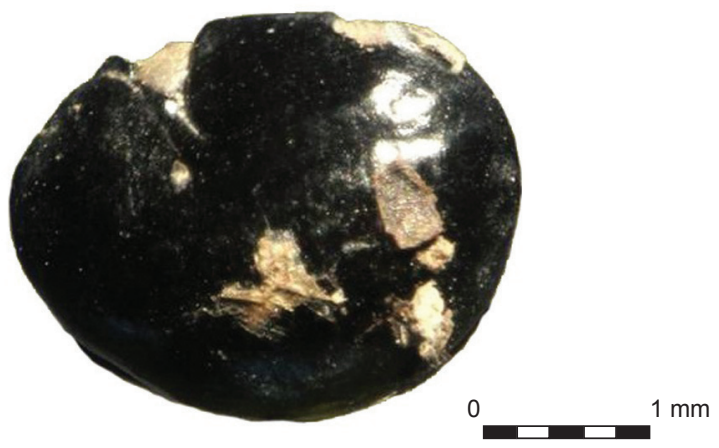

Figure 5. American pokeweed seed (Phytolacca americana) from Hradčany square, sewage tunnel. Photo V. Čulíková. in the second millennium BC in China (Schoch 1996). Citrus species were introduced to Europe after the Arabian conquest of Sicily in the $11^{\text {th }}$ century. Sweet orange and mandarin were dispersed across Europe from the $15^{\text {th }}$ century through trade with the British and Portuguese colonies (Ramon-Laca 2003). Orange fruits were incorrectly connected with the myths of the Hesperides (Caneva, Kumbaric 2010, 169-170) in the Renaissance period. Bitter orange (Citrus aurantium L.) is

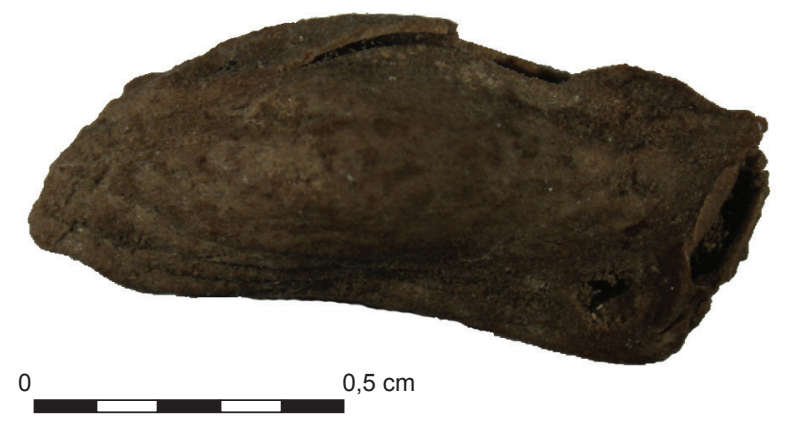

Figure 6. Sweet orange (Citrus sinensis) from Vladislav Hall. Photo J. Kosňovská. 
a tree native to Eastern Africa and tropical Asia. The bitter orange is known to have been planted in Cyprus as early as 1394 (Blamey, Wilson 2004, 123), and in Italy it is recorded in the late medieval period (Castelletti et al. 2001). Citrus trees and shrubs were cultivated in orangeries at major castles and courts of Bohemia. The rind, flower, leaf, and fruit are used in both traditional and modern medicine. At Prague Castle, the leaves and branches of $C$. aurantium were identified in the grave of Princess Eleanor. The finding consists of leaves and small twigs, together with several fragments of flowers, possibly as a bunch added to the grave as a gift (Schoch 1996). The author of the xylotomic identification offers the interpretation of this as a gift related to the date of the Princess' death. She was buried in March, which is the early spring period, when there is a lack of ornamental flowers. The identification of C. aurantium from Eleanor's grave is the first direct archaeobotanical evidence of this species north of the Alps.

Coffee (Coffea arabica L.): The genus Coffea (Rubiaceae) is domestic to the highlands of Ethiopia, with possible disjunct populations in the nearby highland areas of Sudan and Kenya (Charrier, Berthaud 1985). Coffee seeds were transported to south Arabia (Yemen) when slaves were taken from the Sudan region to Arabia around $600 \mathrm{AD}$ (Rieger 2006). The earliest written record of coffee as a drink is mentioned in the work of Rhazes, an Arab physician active in the $10^{\text {th }}$ century (Davidson 2002). The Dervish súfí order and Muslim pilgrims were largely responsible for the distribution of coffee as a drink throughout the Middle and Near East and North Africa by the end of the $15^{\text {th }}$ century. The first European mention of coffee was by Leonhard Rauwolf of Augsburg, who travelled to the Near East and the Levant in 1573-1576 (Ukers 1922; Herde, Tilmann 2010). In 1616, Dutch spies successfully managed to smuggle a coffee plant out of Mocha (Yemen) and started cultivating coffee in India and Java. In 1718, coffee was also brought over to Surinam and in 1720 found its way to France (Rieger 2006). The first coffee plantation in Brazil was established at Pará in 1723 with plants brought from French Guyana (Ukers 1922). The Turkish siege of Vienna in 1685 contributed to the spread of coffee to central Europe, Emperor Leopold I authorised Georg Franz Koltschitzki to set up the first coffeehouse in

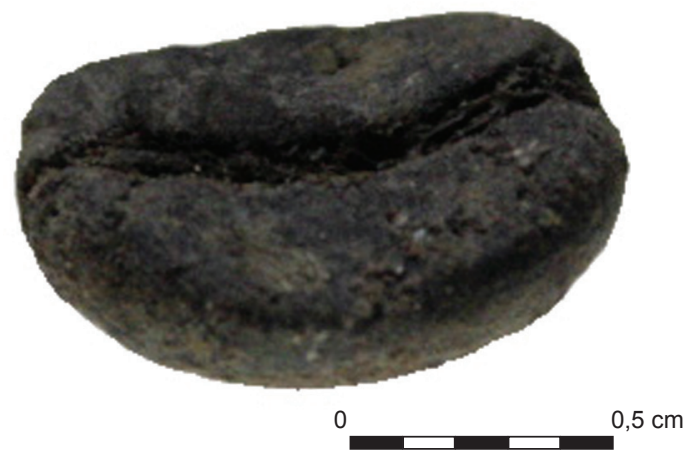

Figure 7. Coffee (Coffea arabica) from Vladislav Hall. Photo J. Kosňovská.
Vienna. The first coffeehouse in Prague was established by the Arab Georgius Deodatus Damascenus in 1714 (Polívka 1908). Coffee is one of the great social drinks of our culture and, along with tea and tobacco, is also an important world trading commodity. Drinking coffee has always been associated with work and activities requiring thought and attention. Archaeobotanical analysis of the waste vault fills at Vladislav Hall provides a unique collection of macroremains. The finding of one coffee seed from a layer dated to the $16^{\text {th }}$ century and to the first half of the $17^{\text {th }}$ century represents the first, and the oldest, archaeobotanical record of C. arabica in central Europe (Figure 7).

Olive (Olea europaea L.): The olive tree from the Oleaceae family is indigenous to the Mediterranean Basin, where its progenitor, the wild olive, Olea europaea subsp. oleaster, is a native plant (Zohary, Hopf 2000, map 14). Olive cultivation appeared for the first time in Levant in the fourth millennium BC and was gradually distributed westwards thanks to the Phoenicians, Etruscans, Greeks and Romans. There is evidence that the utilisation and probable domestication of olives in the Levant took place during the Early Bronze Age (c. 3300-2200 BC) (Liphschitz et al. 1991). The cultivation of this plant could have been introduced from the Levant to Egypt (Newton et al. 2006), Crete and Greece during the Early Bronze Age, consequently to southern Italy. Distribution to northern Africa, Italy and Spain probably followed via the Phoenician expansion (Brun 2003). The presence of $O$. europaea in the Italian landscape is clearly documented by pollen records showing continuous curves at least since 3900 cal years BP in the marine core RF93-30, with the first peaks about one thousand years later before the Roman period (Mercuri et al. 2012) and in the core of Lago di Nemi (Mercuri et al. 2002). An increasing number of archaeobotanical findings indicate macro-remains evidence, for example, in Italy (Castelletti et al. 2001). Olives have been produced on a continuous basis in Italy since the Roman Empire period (Baldini 2003) and transported to the northern provinces, including the areas of the northern boundaries of the Roman Empire (Bakels, Jacomet 2003). In central Europe, the distribution of direct olive findings (stones) is limited to the Roman Empire frontiers. Olive consumption, recorded commonly in archaeobotanical assemblages, is apparent throughout the Roman period, including the specific use of olives as an offering in Roman Mainz (Zach 2002). Archaeobotanical evidence indicates that olive imports in northern Roman provinces were already in operation during the early stage of Roman expansion, which was connected with people with a different culinary tradition (Livarda 2008). There is no evidence of $O$. europea stones north of Limes romanus until the Early Modern Period. After the dissolution of the Roman Empire, evidence of olives declines drastically (Livarda 2008). In medieval Italy, there are numerous written sources documenting cultivation rules and trade registrations related to olives (Fabbri 2006). Written records from the $15^{\text {th }}$ century in Bohemia make mention of olive oil as part of the luxury commodities of the royal Karlštejn Castle kitchen 


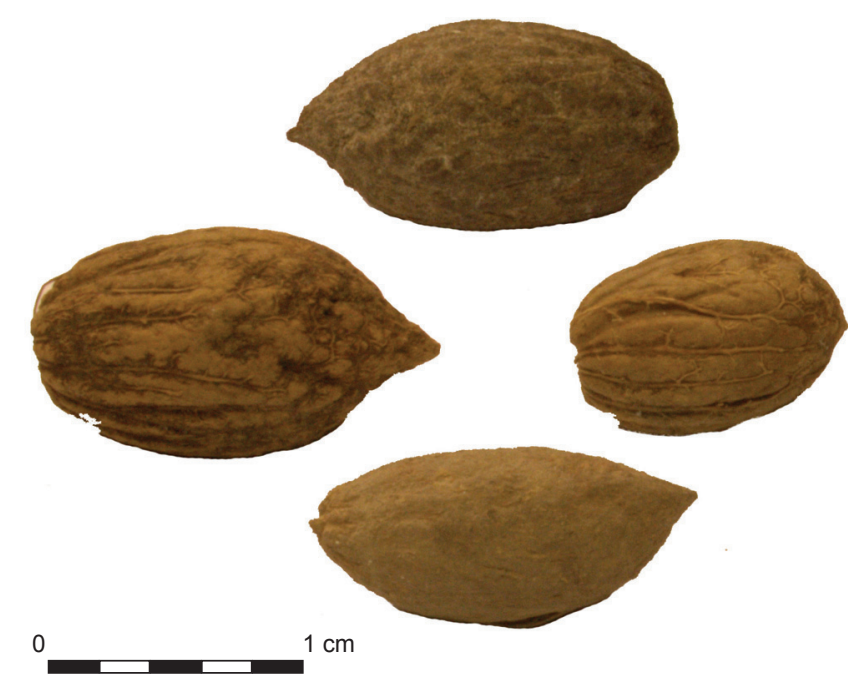

Figure 8. Olives (Olea europaea) from Vladislav Hall. Photo J. Kosňovská.

(Čechura 1993, 83). There is evidence of olive consumption in certain Hansean cities. The records of the Town Council of Reval/Tallinn, of guilds, and of the House of the Blackheads in Riga, do mention the occurrence of olives in purchase lists for festivals in 1530, 1539, 1543, 1544, 1547-1557 (Sillasoo pers. com. 1999; Mänd 2005). The findings of twenty olive stones from Vladislav Hall in Prague Castle are therefore of extraordinary importance (Figure 8). The olive stones are in an extremely good state of preservation, allowing even for the identification of two different morphotypes. A similar example of the recovery of olives as part of a luxury archaeobotanical context involving two different morphological types was recognized in the ducal palace of Ferrara from the second half of the $15^{\text {th }}$ century AD (Bosi et al. 2009).

Peanut (Arachis hypogaea L.): Archaeological records of the peanut (Fabaceae) seem to support its cultivation as having taken place in the period between ca. 3000 and 2500 BC in the Peruvian lowland areas (Pearsall 1992, Smith 2002) occupied by Peruvian Preceramic. Additional evidence is from the desert oases of Peru at El Paraiso. Another author localises the area of peanut domestication in the valleys of the Paraguay and Parana Rivers in the Chaco region (Weiss 2000, Figure 1). Current genetic studies do not exclude both possibilities (Grabiele et al. 2012). The recently accepted subdivision of Arachis hypogaea L. distinguishes two subspecies (subsp. hypogaea and subsp. fastigiata Waldron.). Subsp. hypogaea includes the "Virginia" type groundnut, whereas subsp. fastigiata includes the "Spanish" and "Valencia" types (Shorter, Patanothai 1989; Ntare 2007). The Virginia variety was taken from the Antilles to Mexico soon after 1500 and consequently rapidly introduced to West Africa. The "Spanish" variety was almost certainly taken from Brazil to Africa by the Portuguese shortly after their contact with Brazil in 1500 . There it was combined with the "Virginia" variety, thus producing a great diversity of African

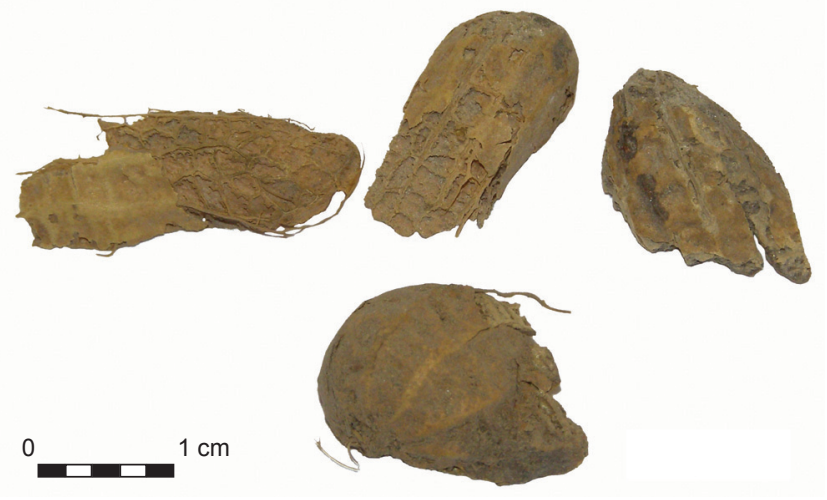

Figure 9. Peanut (Arachis hypogaea) from Vladislav Hall. Photo J. Kosňovská.

landraces. The "Spanish" variety was evidently introduced into Spain in the late $18^{\text {th }}$ century, namely from Brazil via Lisbon. From Spain it was then introduced to Southern France (Kaprovickas 1969). The first written account of the crop is found related to the Spanish entry into Hispaniola in 1502. The first published notice regarding the peanut appeared in Oviedo y Valdés (1535). Archaeobotanical findings of peanuts at Prague Castle are located in the vault fills in Vladislav Hall, dating back to the $16^{\text {th }}$ century and to the first half of the $17^{\text {th }}$ century. They occur as four shells separated from their intact layers. These are the first archaeobotanical findings in central Europe dating to the Early Modern Period. The Prague royal court had direct contact with the Spanish court and therefore the presence of peanut shells in the Early Modern period layers of Vladislav Hall is not surprising, although, the Prague Castle finding of peanuts is a unique occurrence (Figure 9).

Pistachio nut (Pistacia vera L.): The pistachio (Anacardiaceae) is a smaller tree native to central Asia, a large and diverse region where a wealth of $P$. vera genetic resources exist (Khanazarov et al. 2009; Al-Saghir 2009). Pistachio trees combined with sweet almond formed the Early Neolithic forest-steppe (Willcox 1999) covering large parts of the Levant, Turkey and Afghanistan. Charcoal of $P$. vera is quite common in the Bronze Age of Turkey and Syria (Deckers, Pessin 2010). P. vera was introduced into Italy from Syria in $30 \mathrm{AD}$ by the Roman Governor of that Province, Lucius Vitellio, at approximately the same time it was introduced into Spain, followed by its introduction into Sicily (Barone, Marra 2004).

The earliest traces of pistachios being consumed are recorded in Turkey and the Middle East dating back to approximately 7000 BC (Davidson 2002). Pistachio is exceptionally evidenced in the Roman Empire period of NW Europe (Bakels, Jacomet 2003, Table 1).

Apart from the delicious pistachio nuts themselves, mastic and resins are also produced from the plant. It is related to $P$. lentiscus, which also dominated in vegetation in South-western Sicily (Italy) up until 8050 cal BC (Tinner et al. 2009), and P. terebinthus. The triterpenoid mastic 


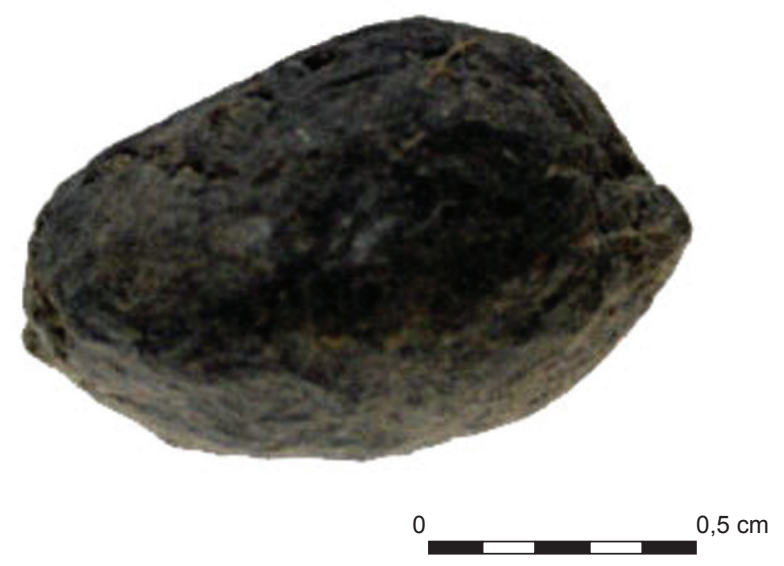

Figure 10. Pistachio nut (Pistacia vera) from Vladislav Hall. Photo J. Kosňovská.

resin from pistachio was a highly valued commodity, which has been identified as occurring in the Late Bronze Age by a Canaanite amphora lifted from a shipwreck at Uluburun (Stern et al. 2008). The same vessels were imported into Egypt from the Levant. Uses of the resin in Egypt included their use as incense and as a varnish for New Kingdom funerary equipment (Howell et al. 2006). Mastic resin was used as the primary component in the embalming process of Egyptian mummies from the $7^{\text {th }}$ century BC (Colombini et al. 2000) and its application as a mechanism of mummification was also known in Greek and Roman times, when pistachio oil was also used in body treatment (Papageorgopoulou et al. 2008). Archaeologically, the nuts of pistachio could be underestimated, for example, as the use of pistachio for resin does not leave traces in the sense of botanical macroremains (Livarda 2011). In the context of the Early Modern archaeobotany of central Europe, Prague Castle findings of pistachio are quite unique. One seed of $P$. vera was recorded in the archaeobotanical collection from the waste vault fill in Vladislav Hall (Figure 10). This unusual archaeobotanical finding indicates the rich and varied nature of royal trade in post-medieval times documented in the milieu of the royal court at Prague Castle.

Pumpkin (Cucurbita pepo L.): It belongs to the family Cucurbitaceae and it is one of the oldest domesticated species from the New World (Barker 2006). At least as early as the terminal Pleistocene period, C. pepo gourds were distributed from an early centre in Mexico to Florida, and probably elsewhere in what is today the eastern United States. In Florida there are also numerous water-based sites where Cucurbita seeds were found, i.e. by the Aucilla River, where the seeds are dated as being 12,500 years old (Newsom et al. 1993). Cucurbita seeds were found in the Mexican cave Guilá Naquitz (Barker 2006). Current radiocarbon reassessing of the cucurbit assemblage from another cave, Coxcatlan (Mexico) provides information on the timing and sequence of the initial appearance of the domesticated plants in the Tehuacan Valley. C. pepo is the earliest documented

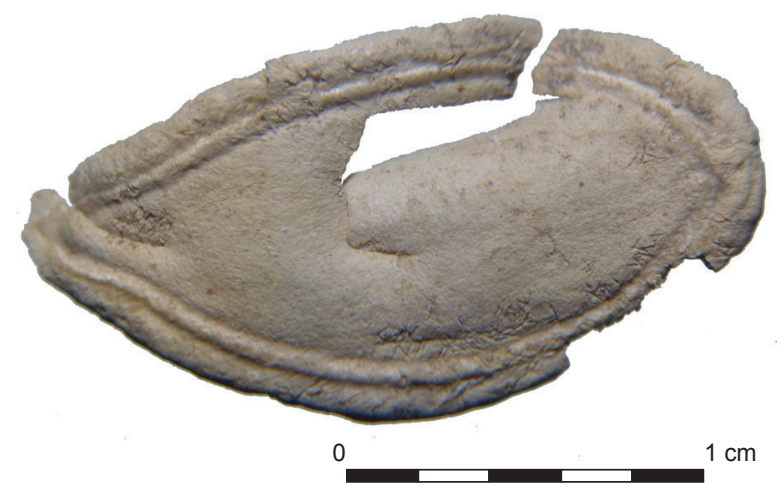

Figure 11. Pumpkin (Cucurbita pepo) from Vladislav Hall. Photo J. Kosňovská.

domesticate, dating here to 7920 years BP cal. (Smith 2005). The literature of the medieval and Early Modern periods occasionally confuses annual pumpkins with melons. The seeds confirmed the extremely rapid introduction of the species, imported to Europe in the beginning of the $16^{\text {th }}$ century (Paris, Janick 2006). Finds of Cucurbita sp. are recorded in Hanseatic towns of the $16^{\text {th }}$ century (Alsleben 2007). In the Czech Republic, the earliest dated seeds of pumpkin come from Ivančice in Moravia, thanks to the finding of a coin dated to a certain point after the first half of the $16^{\text {th }}$ century (Opravil 1985). Fleshy pumpkins were used as a fruit (preparation of compotes, jams). Seeds of C. peppo served as a source of oil and as a medicament. Oil was used as a source of light, in the kitchen and as a specific medicinal agent and aphrodisiac. Numerous findings of pumpkin seeds from different Czech locations indicate their introduction as a commodity import. Evidence of pumpkin seeds from two sites in Prague Castle reveals the early use of this plant in the context of the Early Medieval Period and its possible cultivation in the adjacent Prague gardens (Figure 11).

Sweet almond (Prunus dulcis (Mill.), D.A. Webb): It belongs to the family Rosaceae and it is one of the early domesticated fruit trees in Old World agriculture. It is a native and traditional crop in central and south-west Asia and also in the Mediterranean countries; it is also an important introduced crop in California (Ladizinsky 1998) which is today the main producer, supplying over half of the world production, followed by Spain and Italy (Davidson 2002). Nuts of the wild almond are bitter and eating them in relatively small quantities may be fatal. Poisonous amygdalin cannot be removed by roasting, boiling or leaching and hence wild almond could not be a major source of food; it only could be used for flavouring, as the bitter almond is used today. Numerous genetic modifications have occurred to the sweet nut (Ladizinsky 1998, 195-199). Despite a number of studies about almonds, information on the process and area of domestication and its wild progenitor is still lacking (Ladizinsky 1999). Early archaeological remains of almonds are still scarce and do not permit a clear distinction between 


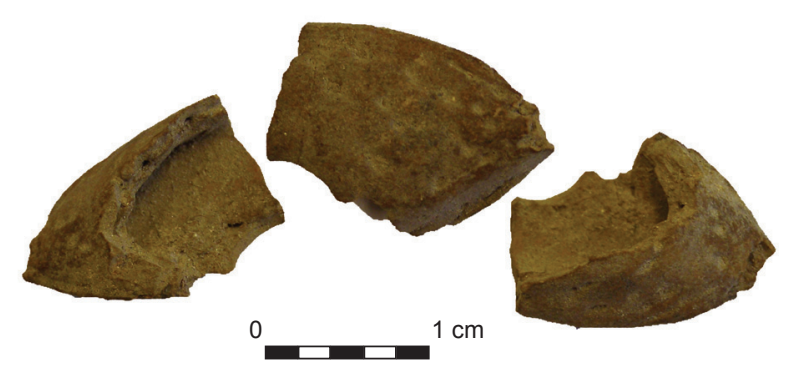

Figure 12. Sweet almond (Prunus dulcis) from Vladislav Hall. Photo J. Kosňovská

the wild and cultivated forms (Zohary, Hopf 2000, 185-188). Very ancient records are from the Epipaleolithic site Oküzini in southwest Anatolia (Martinoli, Jacomet 2004) the Epipaleolithic period at the Jerf al Ahmar site on the Middle Euphrates around 9100-8300 BC (Willcox 2002) and from the Mesolithic and Neolithic settlement layers of Franchthi Cave in Greece. Sweet almond has rare archaeobotanical evidence in the Roman period inside of the Empire frontier (Bakels, Jacomet 2003, Table 1). The significant introduction of almonds as luxury goods to central Europe is recorded in the Middle Ages; in Bohemia it is mentioned in written sources as beginning in the $15^{\text {th }}$ century (Čechura 1993, 83). The archaeobotanical findings of $P$. dulcis stone fragments in the waste fill in Vladislav Hall provide evidence about the use of the almond as an imported luxury food at the Prague Castle in the Early Modern Period (Figure 12).

Rustic tobacco (Nicotiana rustica L.): It is a member of the Solanaceae family. The region of origin of this species N. rustica is Mexico and Texas. The natural distribution of this species of tabacco is limited to parts of South America (Goodspeed 1954). The oldest records of this plant in the eastern part of North America date to circa $100 \mathrm{AD}$; however, the archaeological records of pipes are 1000 years older than the carbonized seeds. Tobacco (several species) was

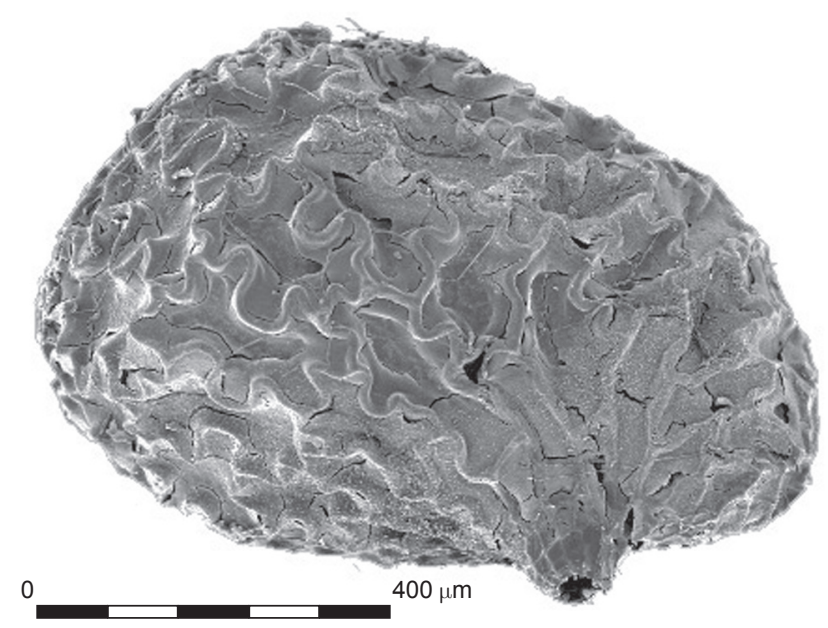

Figure 13. Rustic tobacco (Nicotiana rustica), SEM image, Photo J. Kosňovská. first introduced to Europeans shortly after the momentous landing of Christopher Columbus in 1492. Tobacco seeds were carried to Spain in 1518 (Winter 2000). Seeds of rustic tobacco (Nicotiana rustica, Figure 19) represent the first direct record of this tobacco species in Bohemia and in central Europe (Čulíková 1995, 2007). This species of tobacco was imported by Columbus' sailors from Cuba to Europe as early as March 1493. In comparison with cultivated tobacco (N. tabacum), rustic tobacco was primarily used for medicinal purposes, later also as snuff and chewing tobacco, as it is less suitable for smoking. This is the probable reason why this seed was deposited in the St. Anthony Hospital cesspit. The Prague edition of the Matthioli Herbarium (1596) states: "It now relies on the garden as a foreign guest." Rustic tobacco was found together with other medicinal plant macro-remains in assemblages $\mathrm{A}$ and $\mathrm{C}$ at the Prague Castle and Hradčany sites (Figure 13).

\section{Final remarks and conclusion}

Archaeobotanical findings, newly recorded from Prague Castle and Hradčany in the Early Modern Period indicate, in comparison with the High Medieval layers, that the plant composition of the assemblages shifted towards unusual and exotic species. It reflects the high social status of this key political area of Bohemia and its central economic and trade position. Luxury plants can be divided into several groups of varying utilisation. The first group represents goods of Mediterranean origin which were only imported, including luxury goods such as olives, almonds, peanuts, pistachio nuts, rice and condiments such as black pepper. The second group of products involves commodities such as the common fig, the bitter orange and the common box, whose planting in the gardens and orangeries of the castle and surrounding urban complex is extremely probable. The third group of plants primarily includes herbs of South European import or provenance such as summer savory, basil, garden pepperwort, marjoram and anise, along with technical and decorative plants such as rustic tobacco and american pokeweed. These plants were gradually introduced in the $16^{\text {th }}$ and $17^{\text {th }}$ centuries in the castle gardens. As we have numerous written records for these plants in the Early Modern Period, particularly for commodities such as coffee or pepper, their evidence in archaeobotanical assemblages represents a unique opportunity for their direct physical study.

Similarly important is the potential for morphological, breed and genetic analysis of plant macro-remains, particularly desiccated plant tissues from the waste fill in Vladislav Hall. Plant remains from Prague Castle and the surrounding area represent a valuable historical source of information illustrating the daily and luxury environment at the beginning of the Modern period. It can be stated in general that, in the Early Modern archaeological context recorded at Prague Castle, an unusual concentration of archaeobotanical findings is recorded; these findings demonstrate intense contact with both the Mediterranean world and the Spanish 
environment, through which items from the New World in all probability arrived. The concentration of plants from the exotic regions of Asia and Africa, as well as from the Americas, should be interpreted as the first wave of globalisation which initially affected the environment of the royal court in central Europe.

\section{Acknowledgements}

Thanks must be expressed to Milena Bravermanová from the Prague Castle administration and Iva Herichová and Kateřina Tomková from the Institute of Archaeology in Prague for providing archaeological information. Our research was supported by a grant of the Ministry of Education of the Czech Republic no. MSM6007665801 and by a grant 138/2010/P of the Grant agency, University of South Bohemia, České Budějovice.

\section{References}

AL-SAGHIR, M. G. 2009: Evolutionary history of the Genus Pistacia (Anacardiaceae), International Journal of Botany 5(3): 255-257.

ALSLEBEN, A. 2007: Food consumption in the Hanseatic towns in Germany. In: Karg S (Ed.): Medieval Food Traditions in Northern Europe. Publications from the National Museum. Studies in Archaeology \& History 12, Kopenhagen, 13-31.

ANDERBERG A.-L. 1994: Atlas of seeds and small fruits of NorthwestEuropean plant species with morphological descriptions. Swedish Museum of Natural History, Stockholm.

BAKELS, C, JACOMET S. 2003: Access to luxury foods in Central Europe during the Roman period: the archaeobotanical evidence, World Archaeology 34, 3, 544-557.

BALDINI, E. 2003: Notizie sull'olivicoltura Bolognese. Accademia Nazionale di Agricoltura, Bologna.

BARKER, G. 2006: The Agricultural Revolution in Prehistory. Why did Foragers become Farmers? Oxford University Press, Oxford.

BARONE, E., MARRA, F. P. 2004: The Pistachio Industry in Italy: Current situation and prospects, FAO-CIHEAM - Nucis-Newsletter, Number 12 September 2004, 16-19.

BENEŠ, J., KOLÁŘ, T., ČEJKOVÁ, A. 2006: Xylotomic and dendrochronological analysis in archeology: Changes in the composition type of wood in Prague and in Southern Bohemia, Ve službách archeologie 7, 159-169.

BERGGREN, G. 1981: Atlas of seeds and small fruits of Northwest European plant species with morphological descriptions. Stockholm.

BLAMEY, M., GREY-WILSON, CH. 2004: Wild Flowers of the Mediterranean. A \& C Black, London, 123.

BORKOVSKÝ, I. 1969: Prager Burg zur Zeit der Přemysliden Fürsten. Academia, Praha.

BOSI G., MERCURI A.M., GUARNIERI C., BANDINI MAZZANTI M. 2009: Luxury food and ornamental plants at a Northern Italian Renaissance Court (Este family, $15^{\text {th }}$ cent. A.D.), Vegetation History and Archaeobotany 18.5, 389-402.

BRUN, J.-P. 2003: Le vin et l'huile dans la Mediterranee antique. Viticulture, oleiculture et procédés de transformation. Paris.

BÜTTNER, R. 2001: Mansfeld's Encyclopedia of Agricultural and Horticultural Crops (except Ornamentals). Gatersleben.

CANEVA, G., KUMBARIC, A. 2010: L'inventario della biodiversità vegetale. In: Caneva, G., Carpaneto, G. M. (Eds.): Raffaelo e l' immagine della natura. La raffigurazione del mondo naturale nelle decorazioni delle Logge vaticane. Silvana Editoreale Spa, Milano, 165-207.

CAPPERS, R. T. J., BROKER, R. M., JANS, J. E. A. 2006: Digitale Zadenatlas van Nederland / Digital Seed Atlas of the Netherlands. Groningen.
CAPPERS, R. T. J., NEEF, R., BROKER, R. M. 2009: Digital atlas of economic plants volume $1,2 a, 2 b$. Groningen.

CASTELLETTI, L., CASTIGLIONI, E., ROTTOLI, M. 2001: L'agricoltura dell'Italia settentrionale dal Neolitico al Medioevo. In: Failla, O., Forni, G. (Eds.): Le piante coltivate e la loro storia. Dalle origini al transito in Lombardia nel centenario della riscoperta della genetica di Mendel. Atti del Congresso di Milano (24 giugno 1999), Milano, 33-84.

CHARRIER, A., BERTHAUD, J. 1985: Botanical classification of coffee. In: Clifford, M. N., Willson, K. C.: Coffee: Botany, Biochemistry and Production of Beans and Beverage. Chapman and Hall, London, 13-47.

COlOMBINI, M. P., MODUGNO, F., SilvanO, F., ONOR, M. 2000: Characterization of the balm of an Egyptian mummy from the seventh century B.C., Studies in Conservation 45/1, 19-29.

ČECHURA, J. 1993: Fíky, mandle a rozinky na Karlštejně za husitské revoluce, Historický obzor 4, 82-84.

ČULÍKOVÁ, V. 1995: Zpráva o prvním archeobotanickém nálezu tabáku (r. Nicotiana L.) ve střední Evropě, Archaeologia historica 20, 615-619.

ČULÍKOVÁ, V. 1998: Rostlinné makrozbytky z raně středověkých sedimentů na III. nádvoří Pražského hradu, Archaeologica Pragensia 14, 329-341.

ČULÍKOVÁ, V. 2001: Rostlinné makrozbytky z pěti středověkých lokalit při obvodu centrální části Pražského hradu. In: Ježek, M., Klápště, J. (Eds.), Mediaevalia archaeologica 3, Pražský hrad a Malá Strana. Praha, 303-327.

ČULÍKOVÁ, V. 2007: Zpráva o prvním archeobotanickém nálezu líčidla amerického (Phytolacca americana L.) ve střední Evropě a o dalších druzích užitkových rostlin z Prahy-Hradčan, Archeologické rozhledy 59, 353-370.

ČULÍKOVÁ, V. 2008: Ovoce, koření a léčiva z raně novověké jímky hradčanského špitálu, Archeologické rozhledy 60, 229-260.

ČULÍKOVÁ, V. 2012: Rostlinné zbytky ze zaniklé studny: svědci historie Jiřského náměstí na Pražském hradu ve 13. století, Archeologické rozhledy 64, 479-502.

DAVIDSON, A. 2002: The Penguin Companion to Food. Penguin Books Ltd., London.

de WAARD, P. W. F., ANUNCIADO, I. S. 1999: Piper nigrum L. In de Guzman, C. C., Siemonsma, J. S. (Eds). Plant Resources of South-East Asia. No. 13: Spices, Backhuis Publishers, Leiden.

DECKERS, K., PESSIN, H. 2010: Vegetation development in the middle Euphrates and upper Jazirah (Syria/Turkey) during the Bronze Age, Quaternary Research, 74(2), 216-226.

EDWARDS, H. G. M., STERN, B., JORGE-VILLAR, S. E., DAVID, ROSALIE A. 2007: Combined FT-Raman spectroscopic and mass spectrometric study of ancient Egyptian sarcophagal fragments, Analytical and bioanalytical chemistry, 387/3, 829-836.

FABBRI, A. 2006: L'olivo nella storia dell'agricoltura dell'Italia settentrionale, Comunicazione presentata al convegno dell'Accademia dei Georgofili "L'olio di oliva nel Nord Est", Padova, 17 maggio (on line manuscript).

FROLÍK, J. 1987: Nálezy 14.-17. stol. z hradčanského špitálu, Documenta Pragensia 7, 106-111.

FROLÍK, J., SMETÁNKA, Z. 1997: Archeologie na Pražském hradě. Paseka, Praha-Litomyšl.

FROLÍK, J., NOVÁK, V. 2007: Nález zlaté turecké mince v Praze na Hradčanech - A Turkish gold coin found at the Prague Castle, Numismatický sbornik 22, 60-266.

GOODSPEED, T. H. 1954: The genus Nicotiana, Chronica Botanica 16, 351-356.

GRABIELE, M., CHALUP, L., ROBlEDO, G., SEIJO, G. 2012: Genetic and geographic origin of domesticated peanut as evidenced by $5 \mathrm{~S}$ rDNA and chloroplast DNA sequences, Plant Systematics and Evolution, 298 (6), 1,151-1,165.

HERDE, S, TILMANN, W. 2010: Recent additions to the biography of the Augsburg physician and Orient traveler Leonhard Rauwolf (1535?1596), Sudhoffs Archiv 94 (2), 129-56.

HOŘEJŠÍ, J. 1973: Vladislavský sál Pražského hradu. Odeon, Praha.

JANICK, J., PARIS, H. S. 2006: The Cucurbit Images $(1,515-1,518)$ of the Villa Farnesina, Rome, Annals of Botany 97 (2), 165-176.

JIRÁSEK, V. 1958: Rostliny na našem stole. Orbis, Praha.

KALINA, P. 2009: Benedikt Ried a počátky záalpské renesance. Academia, Praha. 
KAPROVICKAS, A. 1969: The Origin, Variability, and Spread of the Groundnut (Arachis hypogaea). In Ucko, P., Dimbleby, G. W. (Eds.): The Domestication and Exploitation of Plants and Animals. Aldine Pub. Co, Chicago, 427-441.

KARG, S. (Ed.) 2007: Medieval Food Traditions in Northern Europe. Copenhagen.

KHANAZAROV, A. A., CHERNOVA, G. M., RAKHMONOV, A. M., NIKOLYI, L. V., ABLAEVA, E., ZAUROV, D. E., MOLNAR, T. J., EISENMAN, S. W., FUNK, C. R. 2009: Genetic resources of Pistacia vera L. in Central Asia, Genetic Resources and Crop Evolution 56.3, 429-443.

KOMÁRKOVÁ, V. 2002: Praha, Malé náměstí 1. Předběžná zpráva o výsledcích makrozbytková analýzy. MS. Find report. Deposited: LAPE, University of South Bohemia, České Budějovice, Czech Republic.

KOSŇOVSKÁ J. 2011: Archaeobotanical analysis of the waste-vault infill from Vladislav Hall, Prague castle. MS. Master diploma thesis. Deposited: Faculty of Science, University of South Bohemia, České Budějovice, Czech Republic.

KUBÁT, K., HROUDA, L., CHRTEK, J. JUN., KAPLAN, Z., KIRSCHNER, J., ŠTĚPÁNEK, J. 2002: Klič ke květeně České republiky. Academia, Praha.

LADIZINSKY, G. 1998: Plant evolution under domestication. Kluwer Academic Publisher, Dordrecht.

LADIZINSKY, G. 1999: On the origin of almond, Genetic Resources and Crop Evolution 46, 143-147.

LIPHSCHITZ, N., GOPHNA R., HARTMANN, M., BIGER, G. 1991: The beginning of olive (Olea europaea) cultivation in the Old World: a reassessment, Journal of Archaeological Science 18, 441-153.

LIVARDA, A., 2008: New Temptations? Olive, cherry and mulberry in Roman and medieval Europe. In: Baker, S., Allen, M., Middle, S., Poole, K., (Eds.): Food and Drink in Archaeology I. Prospect Books, 73-83.

LIVARDA, A., 2011: Spicing up life in northwestern Europe: exotic food plant imports in the Roman and medieval world, Vegetation History and Archaeobotany 20.2, 143-164.

MÄND, A. 2005: Urban carnival: festive culture in the Hanseatic cities of the eastern Baltic, 1350-1550. Brepols Publishers, Turnhout.

MARTINOLI, D., JACOMET, S. 2004: Identifying endocarp remains and exploring their use at Epipalaeolithic öküzini in southwest Anatolia, Turkey, Vegetation History and Archaeobotany 13(1), 45-54.

MATTHIOLI, P. O. 1596: Herbář neboli bylinář I-III. Praha 2005.

MERCURI, A. M., ACCORSI, C. A, MAZZANTI, M. B. 2002: The long history of Cannabis and its cultivation by the Romans in central Italy, shown by pollen records from Lago Albano and Lago di Nemi, Vegetation history and Archaeobotany 11.4, 263-276.

MERCURI, A. M., MAZZANTI, M. B., TORRI, P., VIGLIOTTI, G., FLORENZANO,A., OLMI, A., N'SIALA, I. M. 2012: A marine/terrestrial integration for mid-late Holocene vegetation history and the development of the cultural landscape in the Po Valley as a result of human impact and climate change, Vegetation History and Archaeobotany 26/2, 1-20.

NEWSOM, L. A., WEBB, D. S., DUNBAR, J. S. 1993: History and geographic distribution of Cucurbita pepo gourds in Florida, Journal of Ethnobiology 13/1, 75-97.

NEWTON, C., TERRAL, J.-F., IVORRA, S. 2006: The Egyptian olive (Olea europaea subsp. europaea) in the later first millennium BC: origins and history using the morphometric analysis of olive stones, Antiquity $80,405-414$.

NTARE, B. R., 2007: Arachis hypogaea L. [online] Record from Protabase. van der Vossen, H. A. M. In: Mkamilo, G. S. (Eds): PROTA (Plant Resources of Tropical Africa). Wageningen, Netherlands. <http:// database.prota.org/search.htm>.Accessed June 21, 2012.

OPRAVIL, E. 1985: Rostlinné zbytky z areálu bývalého bratrského sboru v Ivančicích. In: Šebela, L., Vaněk, J. 1985: Hromadný nález ze studny v areálu bývalého bratrského sboru v Ivančicich (přelom 16. a 17. století). Ivančice, 61-69, 73-74.
PEARSALL, D. 1992: The Origins of Plant Cultivation in South America. In: Cowan, C. W., Watson, P. J. (Eds.): The Origins of Agriculture: An International Perspective. Smithsonian Institution Press. Washington, 173-205.

PADULOSI, S., HADJ-HASSAN, A. (Eds.) 1998: Towards a comprehensive documentation and use of Pistacia genetic diversity in Central and West Asia, North Africa and Europe. Report of the IPGRI Workshop, 14-17 December 1998, Irbid, Jordan.

PAPAGEORGOPOUlOU, C., XIROTIRIS, N. I., ITEN, P. X. BAUMGARTNER, M. R., SCHMID, M., RÜHLI, F. 2009: Indications of embalming in Roman Greece by physical, chemical and histological analysis, Journal of Archaeological Science 36.1, 35-42.

POLÍVKA, F. 1908: Užitkové a pamětihodné rostliny cizich zemí. R. Prombergra, Olomouc.

PYŠEK, P., SÁDLO, J., MANDÁK, B. 2002: Catalogue of alien plants of the Czech Republic, Preslia 74, 97-186.

RAMÒN-LACA, L. 2003: The introduction of cultivated Citrus to Europe via Northern Africa and the Iberian Peninsula, Economic Botany 57/4, 502-514.

RIEGER, M. 2006: Introduction to fruit crops. Haworth Press, Inc, New York.

SCHOCH, W. 1996, Eleonora 1568-1580. Botanische Makroreste aus den Grab. Labor für Quartaere Hoelzer. Adliswil. MS. Unpublished report. Deposited: Prague Castle archive, Prague, Czech Republic.

SHORTER, R., PATANOTHAI, A., 1989: Arachis hypogaea L. In: van der Maesen, L. J. G., Somaatmadja, S. (Eds.): Plant Resources of South-East Asia No. 1. Pulses. Pudoc, Wageningen, 35-39.

SMITH, A.F. 2002: Peanuts: The Illustrious History of the Goober Pea. Chicago.

SMITH, B. D. 2005: Reassessing Coxcatlan Cave and the early history of domesticated plants in Mesoamerica, Proceedings of the National Academy of Sciences of the United States of America 102/27, 9,4389,445 .

STERN, B., HERON, C., TELlEFSEN, T., SERPICO, M. 2008: New investigations into the Uluburun resin cargo, Journal of Archaeological Science 35/8, 2,188-2,203.

TINNER, W., van LEEUWEN, J. F. N., COLOMBAROLI, D., VESCOVI, E., van der KNAAP, W. O., HENNE, P. D., PASTA, S., D’ANGELO, S., LA MANTIA, T. 2009: Holocene environmental and climatic changes at Gorgo Basso, a coastal lake in southern Sicily, Italy, Quaternary Science Reviews 28, 1,498-1,510.

UKERS, W. H. 1922: All About coffee. The Tea and Coffee Trade Journal Company, New York.

VITTE, C., ISHII, T., LAMY, F., BRAR, D., PANAUD, O. 2004: Genomic paleontology provides evidence for two distinct origins of Asian rice (Oryza sativa L.), Molecular Genetics and Genomics 272, 504-511.

WEISS, E. A. 2000: Oilseed Crops. Blackwell, London.

WEISS, E., KISLEV, M. E. 2004: Plant remains as indicators for economic activity: a case study from Iron Age Ashkelon, Journal of Archaeological Science 31, 1-13.

WILLCOX, G. 2002: Charred plant remains from a $10^{\text {th }}$ millennium B.P. kitchen at Jerf el Ahmar (Syria). Vegetation History and Archaeobotany $11 / 1-2,55-60$.

WINTER, J. C. 2000: Tobacco use by Native North Americans: sacred smoke and silent killer. University of Oklahoma Press, Oklahoma.

ZACH, B. 2002: Vegetable offerings on the Roman sacrificial site in Mainz, Germany - short report on the first results, Vegetation History and Archaeobotany 11, 101-106.

ZOHARY, D., HOPF, M. 2000: Domestication of plants in the Old World. The origin and spread of cultivated plants in West Asia, Europe and the Nile Valley. Oxford University Press, Oxford. 